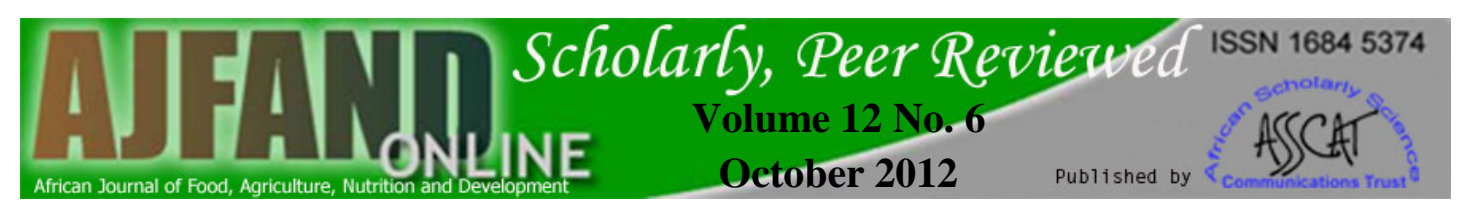

\title{
EFFECT OF SODIUM CHLORIDE CONCENTRATION ON THE FUNCTIONAL PROPERTIES OF SELECTED LEGUME FLOURS
}

\author{
Ahmed SH ${ }^{1}$, Babiker $\mathrm{EE}^{2}$, Mohamed Ahmed IA ${ }^{1^{*}}$, Eltayeb $\mathrm{MM}^{1}$, \\ Ahmed SO ${ }^{3}$ and Faridullah ${ }^{4}$
}

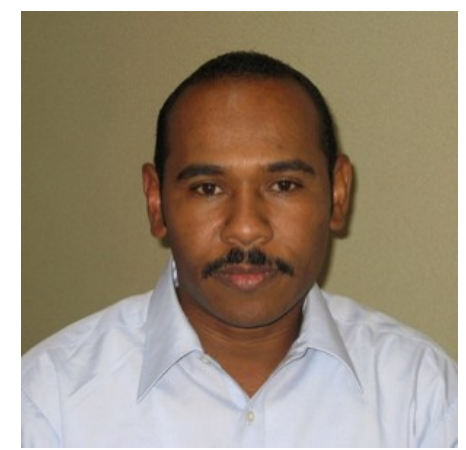

Mohamed Ahmed

*Corresponding author: isamnawa@yahoo.com

${ }^{1}$ Department of Food Science and Technology, Faculty of Agriculture, University of Khartoum, Khartoum North Khartoum North 13314, Shambat, Sudan.

${ }^{2}$ Department of Food Science and Nutrition, College of Food and Agricultural Sciences, King Saud University, P. O. Box 2460, Riyadh 11451, Kingdom of Saudi Arabia.

${ }^{3}$ Department of Food Chemistry, Food Research Center, Ministry of Science and Technology, Khartoum North, P.O. Box 213, Shambat, Sudan.

${ }^{4}$ Department of Environmental Sciences, COMSATS Institute of Information Technology, Abbottabad Pakistan 


\section{ABSTRACT}

Providing safe, nutritious, and wholesome food for poor and undernourished populations has been a major challenge for developing countries. This has led to the necessity of assembling complete food composition tables, yielding information about the traditional foods and on the functional properties of the plant foods that are consumed regularly in the developing countries. Sodium Chloride $(\mathrm{NaCl})$ is the common salt used at household and industry levels to improve palatability of processed foods. Therefore, the main aim of the present study was to investigate the influence of different concentrations of $\mathrm{NaCl}$ on the functional properties of selected legume flours. The effect of increasing concentration of $\mathrm{NaCl}$ on the protein solubility, emulsifying and foaming properties of white bean, pigeon pea, cowpea and hyacinth bean were studied. The results revealed that the protein solubility of pigeon pea, cowpea and white bean flours significantly increased by increasing salt concentration and reached a maximum at $0.4 \mathrm{M} \mathrm{NaCl}$ (for pigeon pea and cowpea flours) and 0.6 $\mathrm{M}$ for white bean flour and then gradually decreased at higher salt concentration. The protein solubility profile of hyacinth bean fluctuated with the salt concentration, with the highest solubility at $0.6 \mathrm{M} \mathrm{NaCl}$ and lowest solubility at $0.4 \mathrm{M}$ $\mathrm{NaCl}$. With the exception of white bean, the maximum emulsifying activity of all selected legume flours was found at $0.4 \mathrm{M} \mathrm{NaCl}$ whereas that of white bean was found at $0.2 \mathrm{M} \mathrm{NaCl}$. Generally, with increasing salt concentration, the emulsifying activity slightly decreased for the legume flours, except for cowpea which fluctuated. Addition of $\mathrm{NaCl}$ significantly decreased the emulsion stability and foaming capacity of the four of selected legume with the maximum improvement being observed at 0.2 $\mathrm{M} \mathrm{NaCl}$, and then decreasing gradually at higher salt concentration. Significant improvement of foaming stability was observed when salt concentration increased. Based on the results of the present study the selected legume flour demonstrated good functional properties following the addition of $\mathrm{NaCl}$, which makes these legume flours potential ingredients for application in salt containing foods.

Key words: Functional properties, Legumes, Protein solubility 


\section{INTRODUCTION}

In most of the developing countries, protein-energy malnutrition is among the most serious problems these countries are facing today. This can be attributed mainly to the ever-increasing population as well as to the enhanced dependence on a cereal-based diet, scarcity of fertile land, and degradation of natural resources [1]. It has been estimated that 800 million malnourished people exist in some of the least developed countries [2]. Providing safe, nutritious, and wholesome food for poor and undernourished populations has been a major challenge for the developing world. Acute shortage, unreliable supply, and elevated costs of protein-rich foods of animal origin in the developing and underdeveloped countries have resulted in the search for inexpensive and reliable alternative sources of protein of plant origin [3].

Legumes (family: Fabaceae) have been recognized to be the 2nd most valuable plant source for human and animal nutrition [4]. They are particularly valuable in some tropical and subtropical regions where there is an acute shortage of animal protein. Legumes are designated to be the 3rd largest family among flowering plants, consisting of approximately 650 genera and 20000 species [5]. Even though several common proteinaceous edible legumes are available on the market, however, the gap between production rate and consumption has remained unmet, and an everincreasing demand has been witnessed [6]. Also, switching by most of the world's population to a protein-rich vegetarian-based diet from animal-based protein has created unwarranted scarcity of plant resources. Thus, legumes have been highlighted as an effective substitute to animal protein as well as being cost effective [7].

For plant proteins to be useful and successful in food application, they should ideally possess several desirable characteristics, referred to as functional properties, as well as providing essential amino acids [8]. These properties are intrinsic chemical characteristics, which affect the behaviour of proteins in food systems during processing, manufacturing, storage and preparation [8]. They include solubility, water and oil absorption capacity, gelation, foaming and emulsifying properties.The properties of proteins that determine their uses in foods are collectively called functional properties. Many factors influence the functional properties of proteins such as moisture, temperature, $\mathrm{pH}$, reaction time, chemical additives, mechanical processing and ionic strength and amount [9]. Functional properties denote those physicochemical properties of food proteins that determine their behaviour in food during processing, storage and consumption [10]. Traditionally, salt $(\mathrm{NaCl})$ has been widely used in foods to enhance flavour, preserve food, and improve processing. However, in recent decades with increasing consumption of many different processed foods containing high levels of sodium, the perception of dietary salt has evolved to a point where it is now considered a potential health threat. Although sodium is an essential nutrient, the majority of the world's population consumes far in excess of what is required, and more than recommended dietary guidelines. High sodium intake is a cause of high blood pressure, cardiovascular disease, and renal disease. It is also associated with an increased risk of stomach cancer, and osteoporosis. Therefore, this study aimed to investigate the influence of different concentration of $\mathrm{NaCl}$ on the

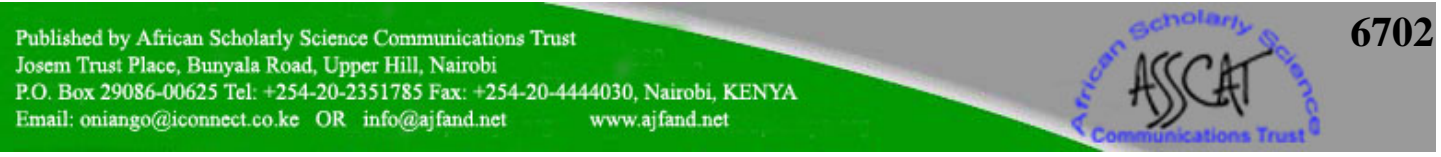




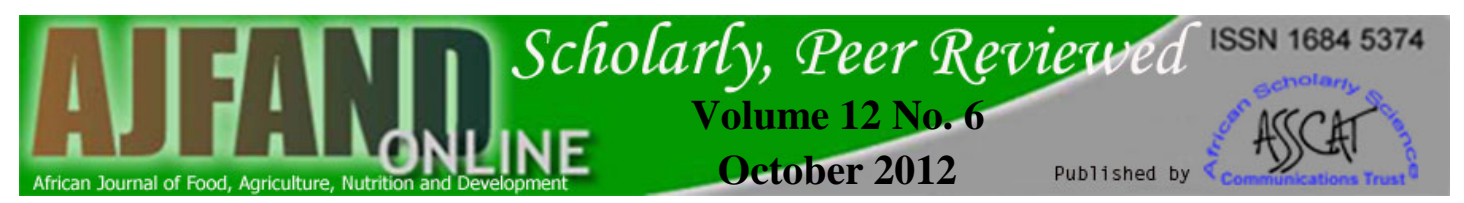

functional properties of the flours of white bean, pigeon pea, cowpea and hyacinth bean.

\section{MATERIALS AND METHODS}

\section{Materials}

White bean (Phaseolus vulgaris), pigeon pea (Cajanus cajan), cowpea (Vigna unguiculata (L.), and hyacinth bean (Lablab purpureus) were obtained from the local market, Khartoum, Sudan. Unless otherwise stated, all chemicals used in this study were of reagent grade.

\section{Preparation of raw defatted legume flour}

The legume seeds were first cleaned, freed from foreign matter and milled in a laboratory miller (Buhler MLI 204, Buhler-Miag, Milano, Italy) and fined in a house miller (Fritsch Pulverisette-14, Fritsch GmbH, Idar-oberstein, Germany) to pass through a $0.4-\mathrm{mm}$ screen. To extract oil from the legume flours, cold extraction method was used. Legume flour were placed in a conical flask and mixed with hexane at ratio of 1:10 (flour: hexane). The mixture was stirred using a mechanical shaker (Model SFI, Stuart Scientific, Stone, Staffordshire, UK) for 16 hours and then filtered. The filtrate was washed again with hexane to remove traces of oil. The mixture was filtered again and the oil-free flour was dried at $60^{\circ} \mathrm{C}$ for 16 hours in an oven drier. The dried flour was then ground to pass through a $0.4-\mathrm{mm}$ mesh screen and stored at $0{ }^{\circ} \mathrm{C}$ for further analysis. Fat was determined according to the Soxhlet method of AOAC [11].

\section{Measurement of protein solubility at different $\mathbf{N a C l}$ concentrations}

Protein solubility was determined by the method of Aoki et al. [12]. The samples of the defatted seed flour $(0.2 \mathrm{~g})$ were used for the determination of solubility at different $\mathrm{NaCl}$ concentrations $(0.2,0.4,0.6,0.8,10$ and $1.2 \mathrm{M})$. Samples were dissolved in $0.1 \mathrm{M}$ potassium phosphate buffer with a $\mathrm{pH}$ of 7.0 and shaken with a vortex mixer (scientific industries, adjusted on digit 4 to work on touch) for 10 seconds, and the turbidity was measured at $500 \mathrm{~nm}$. Values obtained are means of triplicate samples.

\section{Measurement of emulsifying properties}

The emulsifying properties of sample solutions were determined by the method of Pearce and Kinsella [13]. To prepare the emulsion, $1.0 \mathrm{ml}$ of corn oil and $3.0 \mathrm{ml}$ of flour solution (2\%) in $0.1 \mathrm{M}$ potassium phosphate buffer $(\mathrm{pH} 7.0)$ were shaken together and homogenized in Ultra Turrax (Hansen Co., West Germany) at $12.000 \times \mathrm{g}$ for $1 \mathrm{~min}$ at $20^{\circ} \mathrm{C}$. The mixture was poured into centrifuge tubes and centrifuged at $2000 \times g$ for $5 \mathrm{~min}$. Then poured into $50 \mathrm{ml}$ measuring cylinders and stayed a few minutes until the emulsified layer was stable. Emulsifying activity (EA) as a function of different $\mathrm{NaCl}$ concentration was determined according to the formula:

EA $(\%)=\frac{\text { Height of emulsified layer }}{\text { Height of the total content in the cylinder }} \times 100$

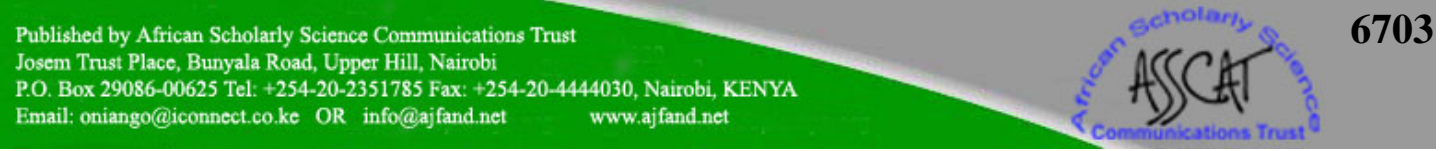


For the emulsion stability, about $50 \mu \mathrm{L}$ of the homogenized mixture was taken from the bottom of the container at different times and $\mathrm{NaCl}$ concentration, and diluted with $5 \mathrm{ml}$ of $0.1 \%$ sodium dodecyl sulphate (SDS) solution. The turbidity of the diluted samples was then determined at $500 \mathrm{~nm}$. The emulsion stability at different salt concentrations was estimated by determining the half time of the turbidity measured immediately after emulsion formation [14]. Values obtained are means of triplicate samples.

\section{Foaming properties}

Foaming capacity of the samples was determined by following the procedure described by Lawhon et al. [15]. Two grams of the sample were blended with $100 \mathrm{ml}$ buffer at different $\mathrm{NaCl}$ concentration (0.2, 0.4, 0.6, 0.8, 1.0 and 1.2) in a Moulinex blender at high speed for $2 \mathrm{~min}$. The mixture was poured into a $250 \mathrm{ml}$ measuring cylinder and the foam volume was recorded after 30 seconds.

$$
\text { FC }(\%)=\frac{\text { Volume after whipping }- \text { Volume before whipping }}{\text { Volume before whipping }} \times 100
$$

The foam stability (FS) was conducted according to Ahmed and Schmidt [16]. FS (\%) was determined as a function of $\mathrm{NaCl}$ concentration $(0.2,0.4,0.6,0.8,1.0$ and $1.2 \mathrm{M})$. The FS was recorded at 15 min interval for 2-3 hours after pouring the material in a cylinder.

FS $(\%)=\frac{\text { Foam volume after } 15 \mathrm{~min}}{\text { Initial foam volume }} \times 100$

\section{Statistical analysis}

Statistical analysis of the data obtained in this study was carried out using standard analysis of variance (ANOVA) method [17]. Duncan's multiple range test was used to separate means. Significance was accepted at $(\mathrm{P} \leq 0.05)[18]$.

\section{RESULTS}

\section{Effect of $\mathrm{NaCl}$ concentration on the protein solubility}

The results of the solubility profile of selected legume flours at different $\mathrm{NaCl}$ concentrations are shown in Figure 1. The protein solubility of pigeon pea and cowpea flours significantly increased by increasing salt concentration and reached maximum at $0.4 \mathrm{M} \mathrm{NaCl}$ and then gradually decreased. The protein solubility of white bean flour also increased with increasing salt concentration with a maximum solubility at $0.6 \mathrm{M} \mathrm{NaCl}$. The protein solubility profile of hyacinth bean fluctuated with the salt concentration, with the highest solubility at $0.6 \mathrm{M} \mathrm{NaCl}$, and the lowest solubility at $0.4 \mathrm{M} \mathrm{NaCl}$. 

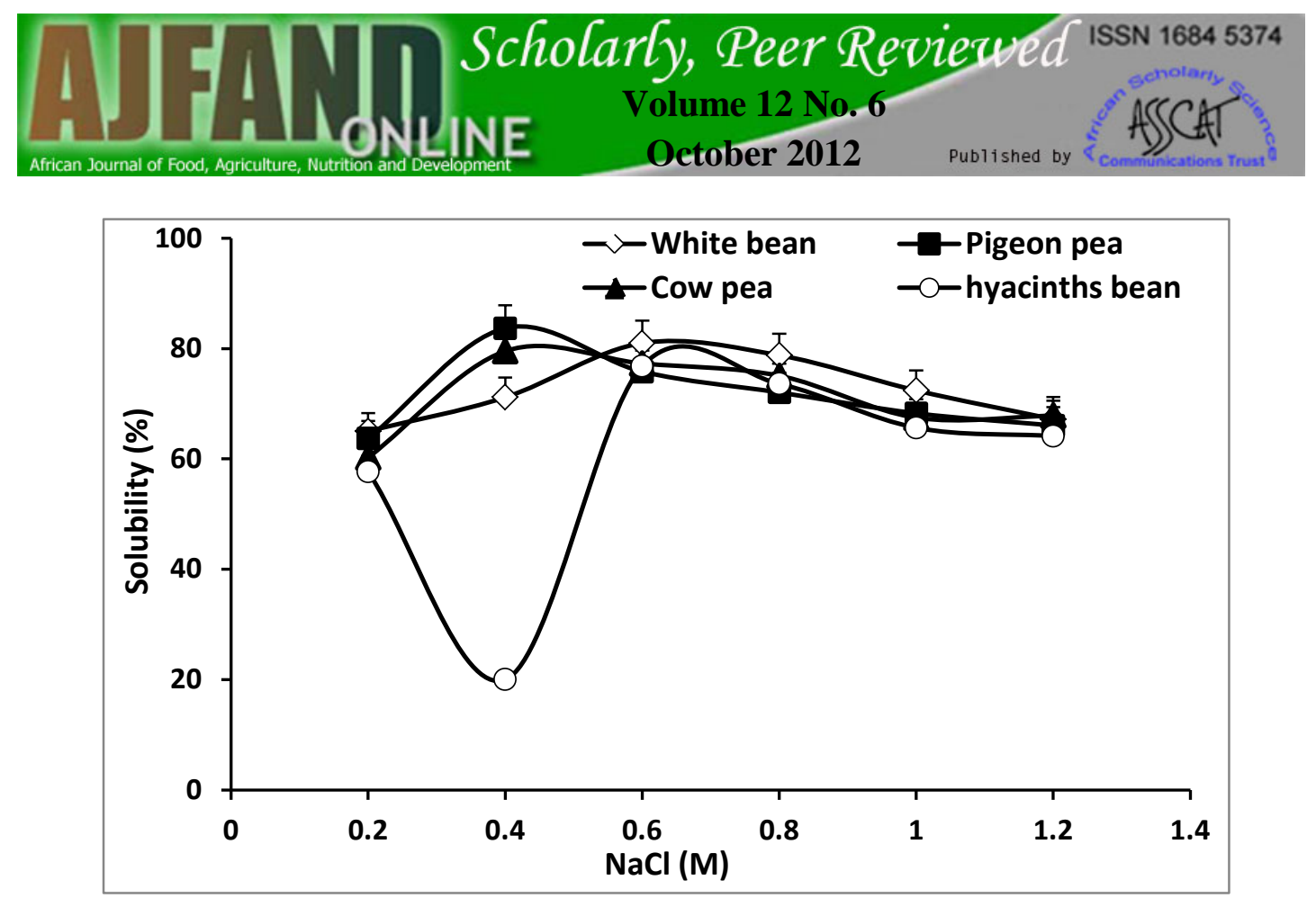

Figure 1: Effect of different $\mathrm{NaCl}$ concentration on nitrogen solubility of selected legume flours

Effect of $\mathrm{NaCl}$ concentration on the emulsifying activity (EA) and emulsion stability (ES) of selected legume flour

Emulsifying properties are usually attributed to the flexibility of solutes and exposure of hydrophobic domains. Food emulsions are thermodynamically unstable mixtures of immiscible liquids. The formation and stability of an emulsion is very important in food systems such as salad dressing. The results of the EA and ES of selected legume flours as affected by salt concentration are presented in Figure 2. With the exception of white bean, the maximum EA of all selected legume flour was found at $0.4 \mathrm{M} \mathrm{NaCl}$ whereas that of white bean was found at $0.2 \mathrm{M} \mathrm{NaCl}$. Generally, with increasing salt concentration the EA slightly decreased for the legume flours with an exception for cowpea flour. Addition of $\mathrm{NaCl}$ significantly decreased the ES of all the selected legume flours (Fig. 3). At low concentration of ionic strength, the values of ES were higher and then decreased. 

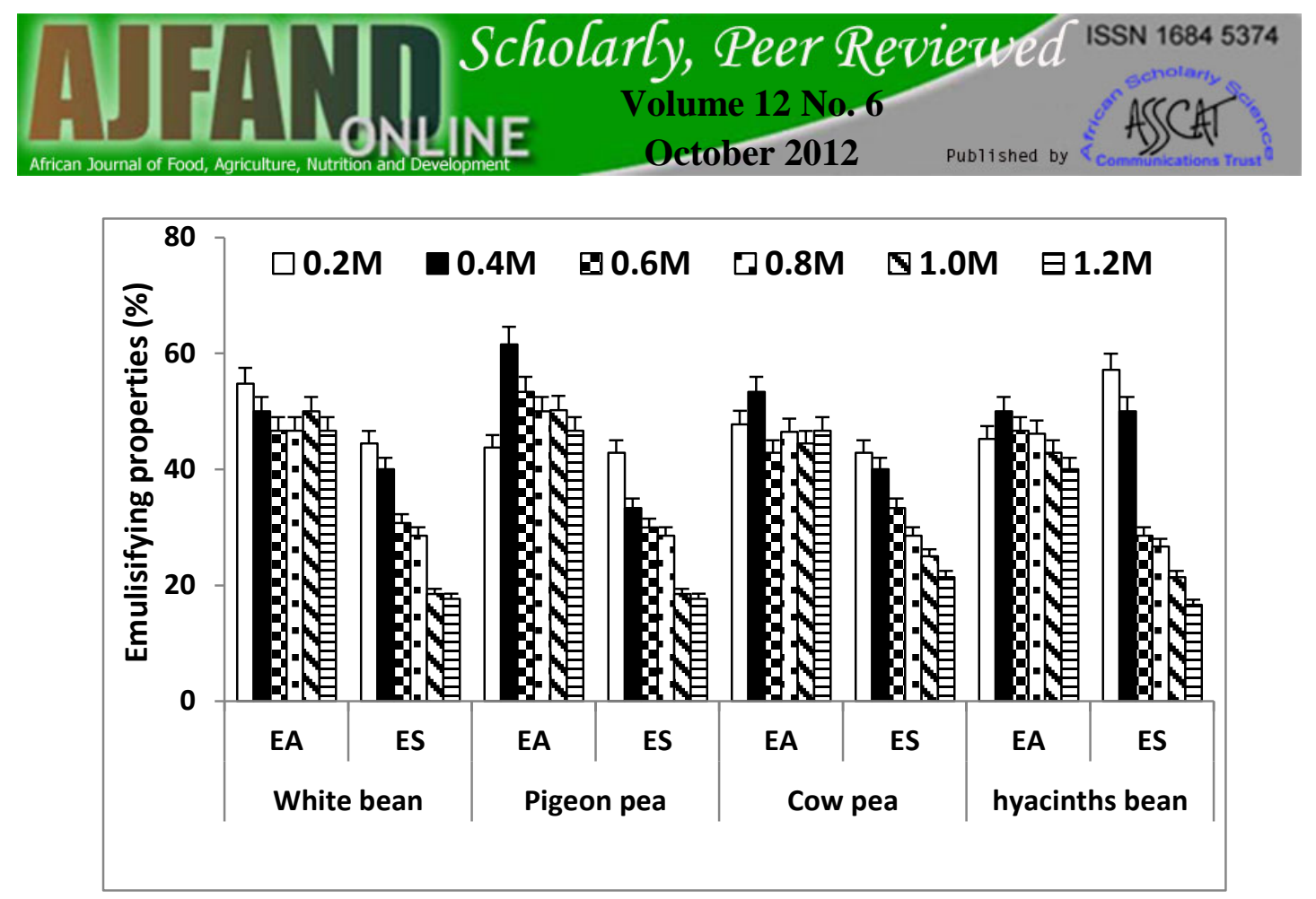

Figure 2: Effect of $\mathrm{NaCl}$ on the emulsifying activity and stability of selected legume flour

Effect of $\mathrm{NaCl}$ concentration on foaming capacity (FC) and foam stability (FS) of selected legume flour

The results on the effect of different concentrations of $\mathrm{NaCl}$ on the $\mathrm{FC}$ of selected legume flours are presented in Figure 3. The maximum improvement of FC was observed at $0.2 \mathrm{M} \mathrm{NaCl}$, which decreased gradually at higher salt concentration due to salting out effect of $\mathrm{NaCl}$.

Results on the effect of $\mathrm{NaCl}$ concentration on the foam stability of selected legume flour are shown in Fig. 4a-d. The lowest FS of selected legume flour was found to be at $0.2 \mathrm{M} \mathrm{NaCl}$. As the salt concentration increased, the FS significantly improved at a given time. 

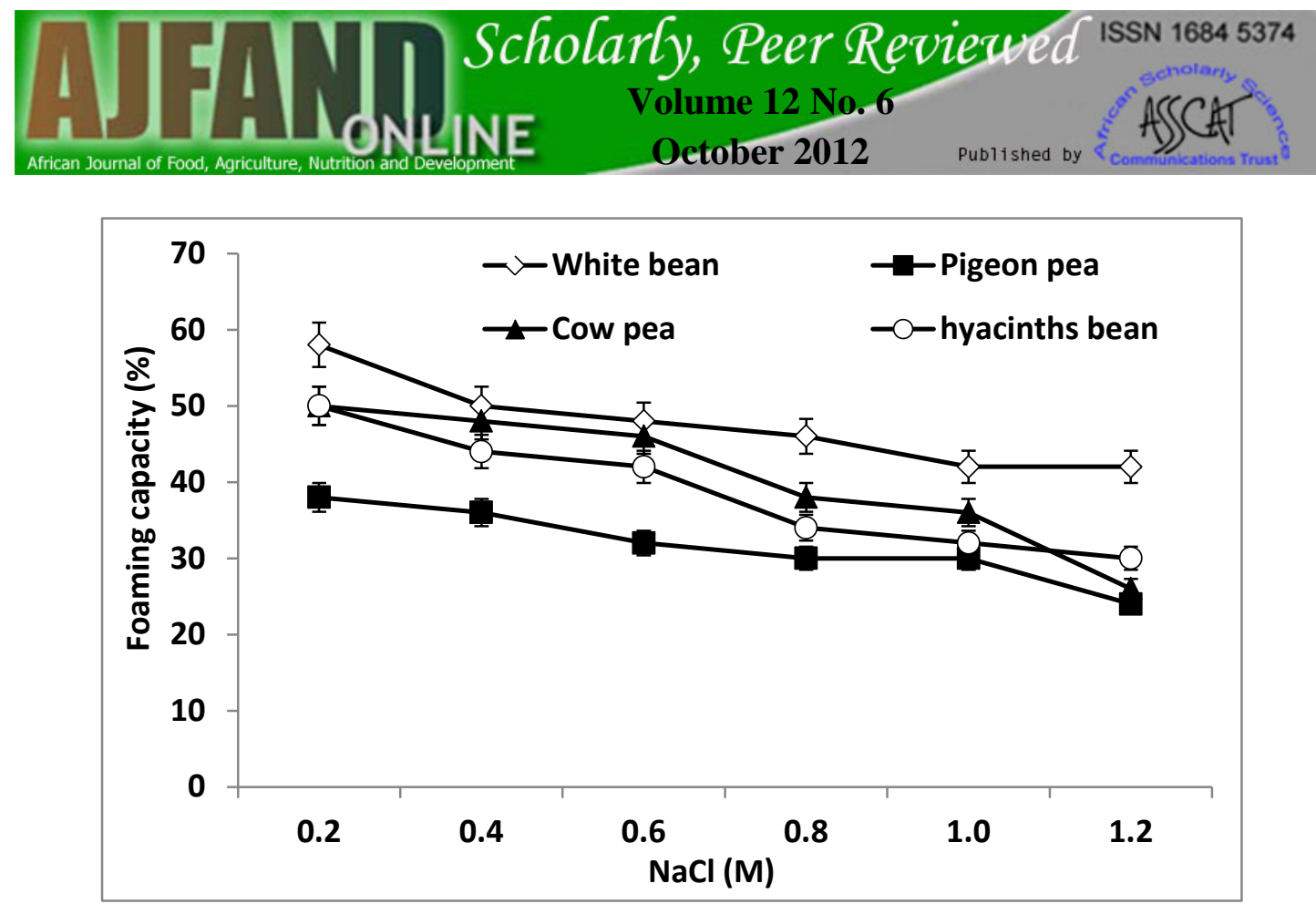

Figure 3: Effect of $\mathrm{NaCl}$ on the foaming capacity (FC) of selected legume flour

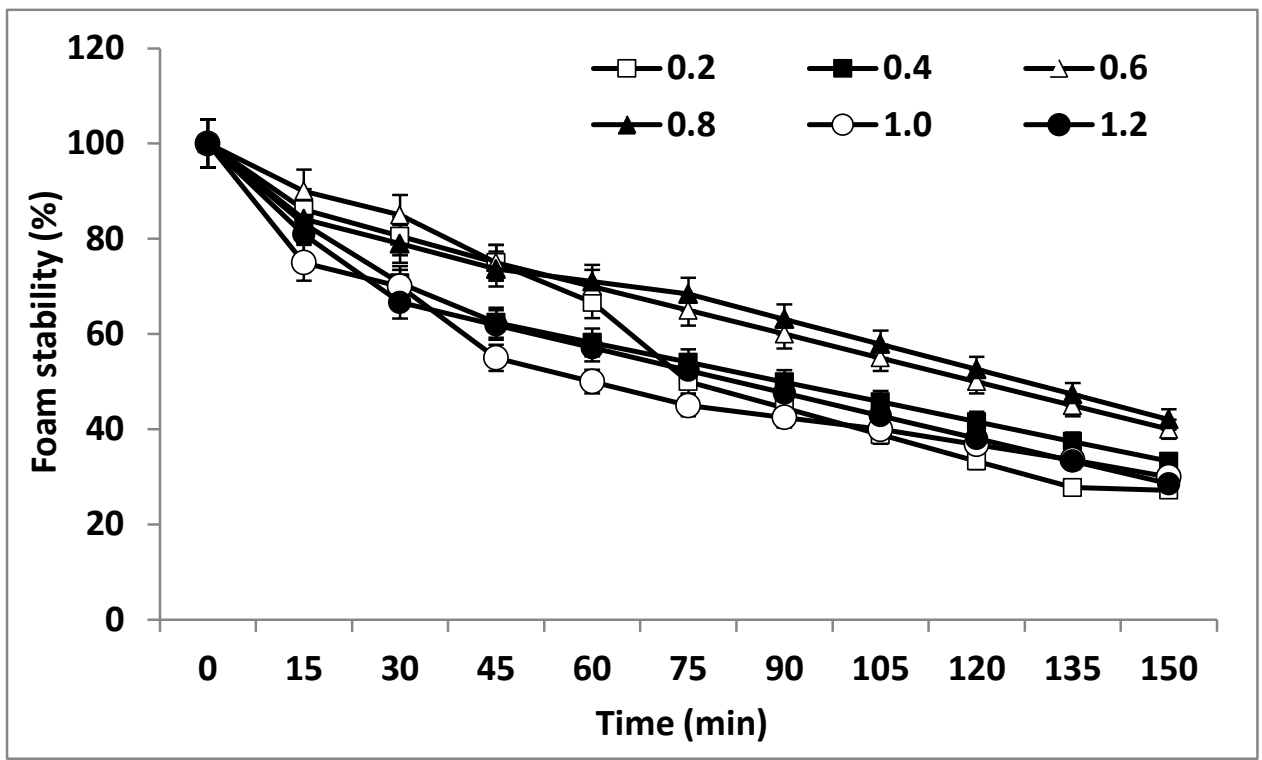

Figure 4a: Effect of $\mathrm{NaCl}$ on the foaming stability of hyacinths bean flour 

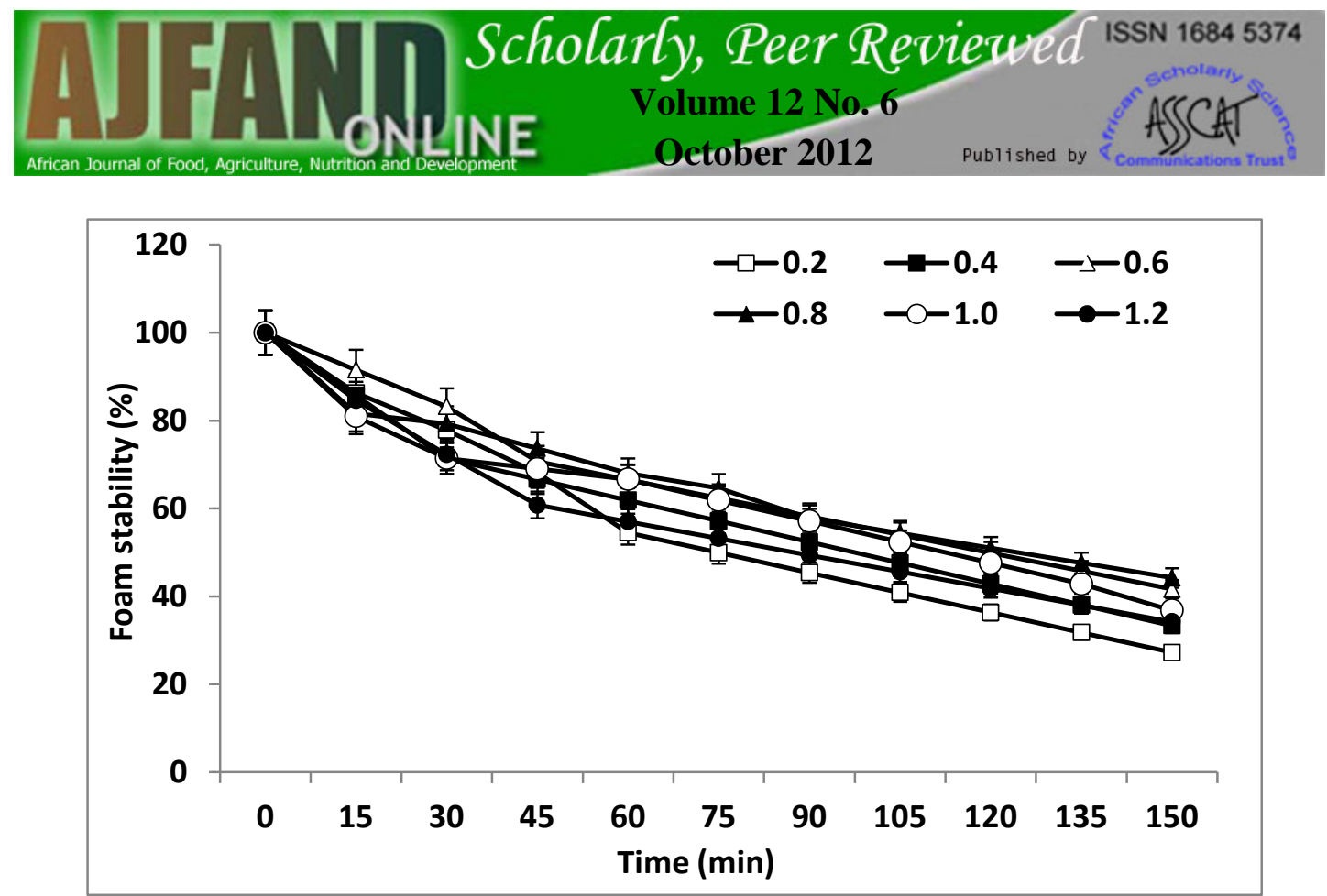

Figure 4b: Effect of $\mathrm{NaCl}$ concentration on foaming stability of white bean flour

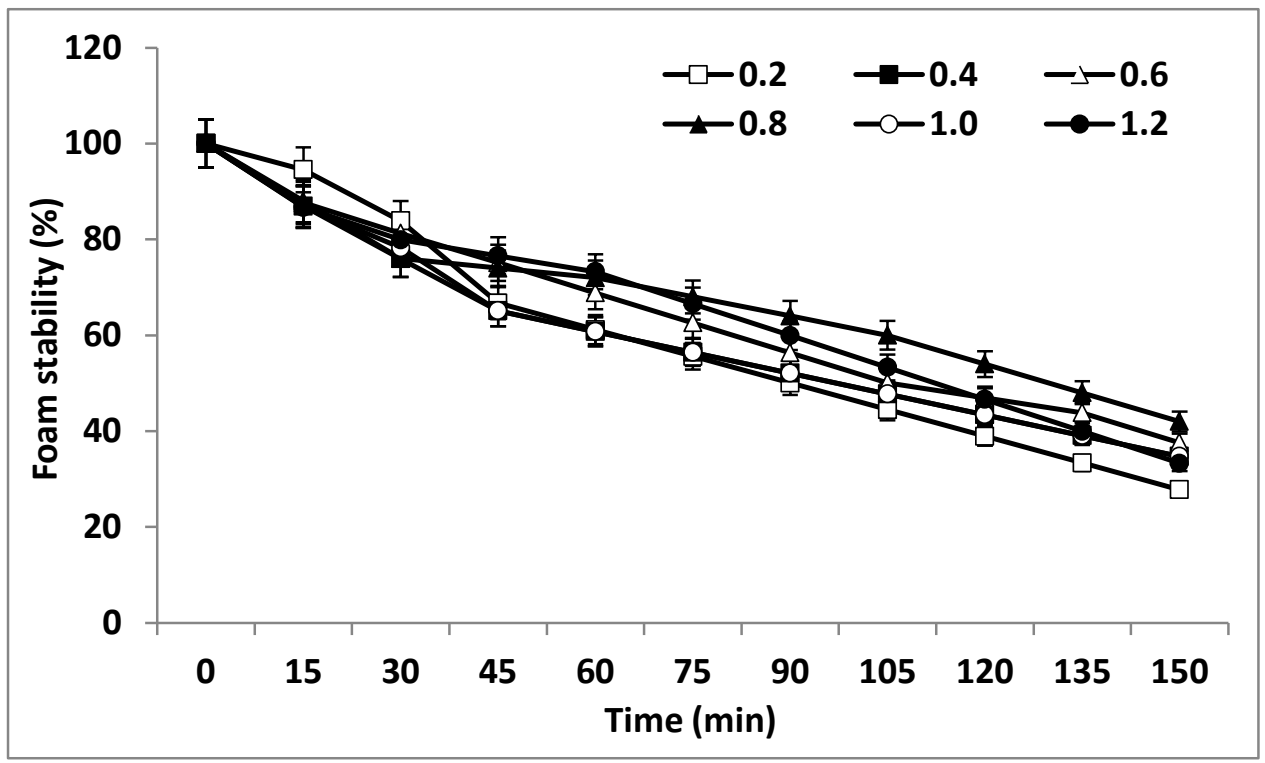

Figure 4c: Effect of $\mathrm{NaCl}$ concentration on foaming stability of cow pea flour 

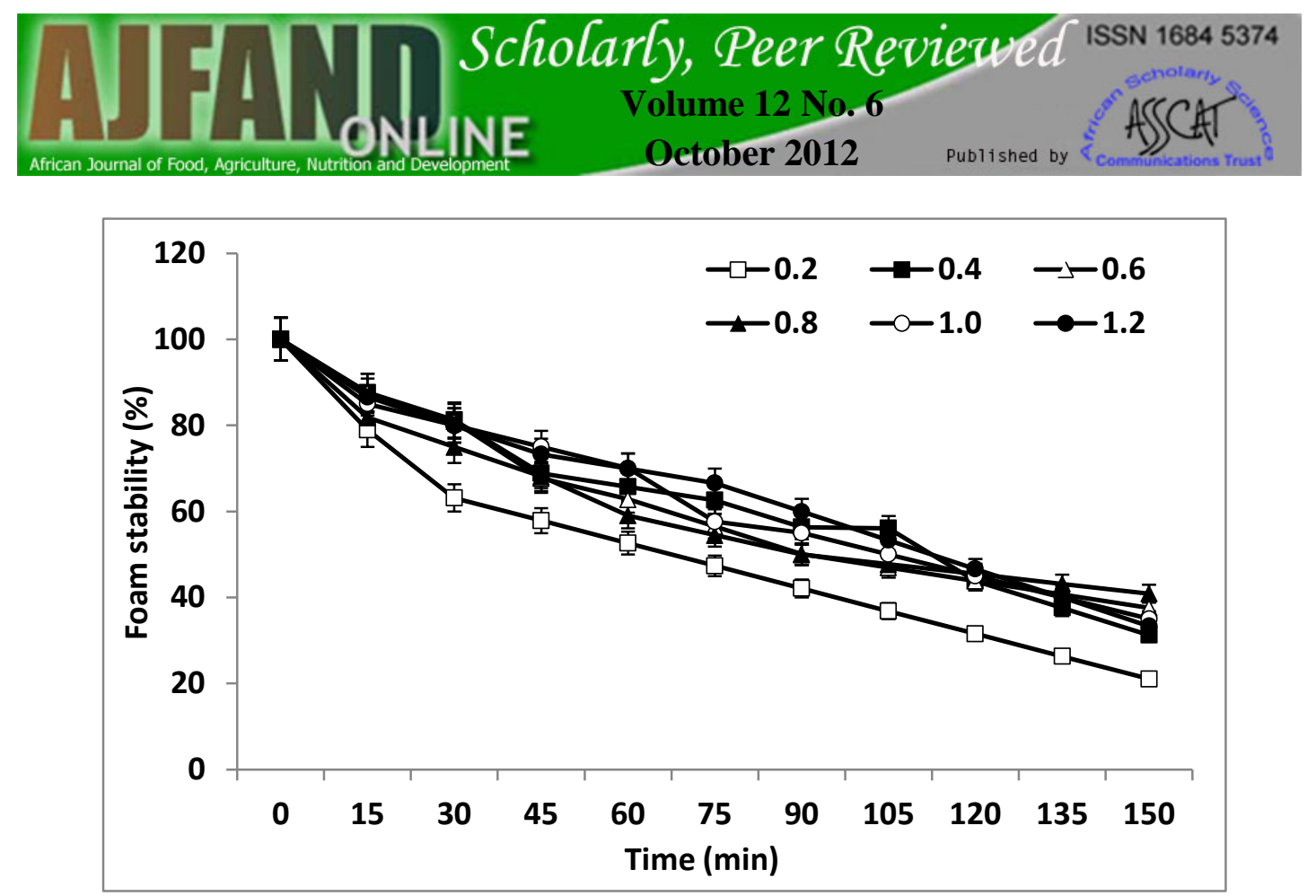

Figure 4d: Effect of $\mathrm{NaCl}$ concentration on foaming stability of pigeon pea flour

\section{DISCUSSION}

In the present study, attempts were made to determine the effect of increasing concentration of $\mathrm{NaCl}$ on the protein solubility, emulsifying and foaming properties of selected legume flours. The results of the present study demonstrated that the elevated concentration of $\mathrm{NaCl}$ significantly enhanced the functional properties of the selected legume flours. It was previously reported that addition of $\mathrm{NaCl}$ greatly improved the solubility of the protein isolate of these legumes and further improvement was observed after polymerization by transglutaminase of the protein isolate of the legumes [19]. The enhancement and reduction of the solubility with increasing salt concentration could be attributed to the salting in and salting out effect of $\mathrm{NaCl}$. Addition of $\mathrm{NaCl}$ at high concentration causes negatively charged chloride ions to interact with the positively charged proteins, thereby decreasing electrostatic repulsions and enhancing hydrophobic interactions. The increase in hydrophobic interactions would result in a higher tendency for the protein to form insoluble aggregates, thus decreasing solubility [20]. Sodium chloride has been shown to improve the extractability of legume proteins, and similar profiles for the percentages of proteins extracted from different legumes by increasing concentration of $\mathrm{NaCl}$ have been reported [21]. Osman et al. [22] observed that chickpea flour had lower extractability of protein at $0.2 \mathrm{M}$ compared to that treated with distilled water. Kinsella [23] observed that the effect of ionic strength on protein solubility presumably involves electrostatic, salvation, and salting-in and salting out phenomena. The solubility of the nitrogenous constituents of mug bean, pea beans and red kidney beans reach maxima at $\mathrm{NaCl}$ concentration of $0.75 \mathrm{M}, 0.5 \mathrm{M}$, and $0.75 \mathrm{M}$, respectively [23]. 
Emulsifying activity (EA) reflects the ability of the sample to rapidly adsorb at the water-oil interface during the formation of the emulsion, thereby preventing flocculation and coalescence. EA is one of the most important functional properties of food proteins. Separate hydrophobic and hydrophilic regions are distributed in protein molecules (amphiphilic structure). This structure is required for the formation of emulsions [8]. The results of the present study demonstrated that with increasing salt concentration the EA of the legume flours slightly decreased, except for cowpea which fluctuated. Similar results were reported by Osman et al. [22] who stated that the EA of chickpea was higher in distilled water and then decreased at $0.2 \mathrm{M} \mathrm{NaCl}$, but no obvious reduction was observed after $0.6 \mathrm{M}$ salt concentration. Also Monteiro and Prakash [24] reported the turbidity of the total protein peanut decreased considerably at $0.3 \mathrm{M} \mathrm{NaCl}$. They also stated that above $0.3 \mathrm{M} \mathrm{NaCl}$ concentration, EA increased with increasing $\mathrm{NaCl}$ concentration. It has also been reported that EA of cowpea globulin isolate was higher at low $\mathrm{NaCl}$ concentration at various $\mathrm{pH}$ conditions [25]. In the current study, the behavior of pigeon pea flours in response to increased salt concentration resembled that of hyacinth bean, but on the other hand they differed from phaseolus and cowpea. These findings suggest that $\mathrm{NaCl}$ probably affected the EA of the flours proteins by other mechanisms, in addition to its effect on protein solubility. The observed differences in the response of emulsifying properties to changes in salt concentration between these legume flours may be due to differences in their subunit molecular weight distribution and amino acid composition. McWatters and Cherry [26] reported that the emulsion, foaming and thickening properties of cowpeas may be influenced by their high carbohydrate starch component, which may interact with protein and other component in the starch.

Emulsions are highly unstable systems but proteins play some important roles during emulsification especially in emulsion stability. The emulsion stability (ES) is important since success of an emulsifier depends on its ability to maintain the emulsion in subsequent processing steps such as cooking and canning. The current study revealed that the addition of $\mathrm{NaCl}$ significantly decreased the ES of all the selected legume flours. A similar observation was reported by Osman et al. [22] who stated that addition of $\mathrm{NaCl}$ significantly decreased the ES of untreated chickpea flour. Similar observation was also reported by Odoemelam [27] who stated that, addition of $\mathrm{NaCl}$ improved the emulsion stability of processed jack fruit flour. Wanger and Guegeon [28] attributed the higher ES of soy protein at low ionic strength to the dissociation of oligomeric structure of HS glycinin and subsequent improvement of the surface properties. It has been reported that addition of $\mathrm{NaCl}$ increased both emulsifying activity and stability. However, further increase in ionic strength progressively reduced both emulsifying activity and emulsion stability. Increase in ionic strength up to $0.2 \mathrm{M}$ encouraged unfolding of protein molecules and a subsequent increase in protein solubility [25]. This increase in protein solubility enhanced a rapid migration to the oil-water interface and improved emulsifying activity of the protein. With further increase in ionic strength $(>0.2 \mathrm{M})$, screening of the surface charges increased and this encouraged protein-protein interaction but reduced protein-oil interaction.

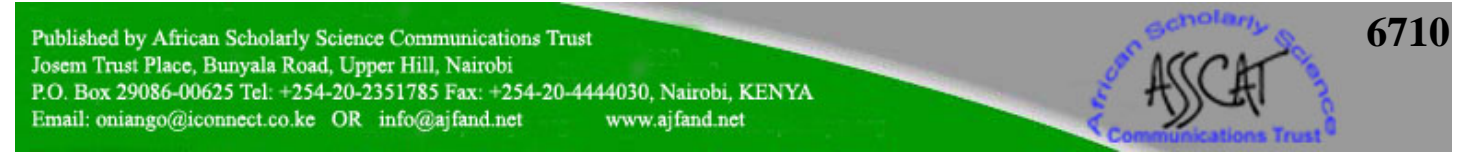


The foaming capacity (FC) of a protein refers to the amount of interfacial area that can be created by the protein while foam stability (FS) refers to the ability of protein to stabilize against gravitational and mechanical stresses [10]. Foam formation and foam stability are a function of the type of protein, $\mathrm{pH}$, processing methods, viscosity and surface tension. The present results supported the findings of Osman et al. [22] who found that the maximum improvement of FC for chickpea was at $0.2 \mathrm{M} \mathrm{NaCl}$, while higher FC was observed at low salt concentration. Variation in these results is likely to be due to chemical difference in the tested protein. Similar results were reported by Narayana and Rao [29], who observed that the FC of raw winged bean flour at lower concentration of $\mathrm{NaCl}(0.2 \mathrm{M})$ increased to a maximum value and there was no further increase beyond this concentration. Also Giami [30] reported that the foaming property of cowpea flour was improved in $0.2 \mathrm{M} \mathrm{NaCl}$. Higher FC at low salt concentration might be due to the improvement of the protein solubility at the interface of the colloidal suspension during foam formation, thus improving foaming capacity.

Foam stability (FS) describes the ability of proteins to form a strong cohesive film around an air vacuole, which resists air diffusion from the vacuole. The current study showed lowest FS of selected legume flour at $0.2 \mathrm{M} \mathrm{NaCl}$ which significantly improved when the salt concentration increased. Similarly, it has been reported that with an increase in $\mathrm{NaCl}$ concentration the FS of chickpea flour was significantly increased [22]. The lower stability at $0.2 \mathrm{M} \mathrm{NaCl}$ is possibly because of the effect of salt on improving the protein solubility at the interface of the colloidal suspension during foam formation, which retarded the partial denaturation of the surface polypeptides of proteins that are necessary for protein-protein interactions and stability [8]. The enhancement of the FS might be due to cross linking of protein molecules and creation of films with better viscoelastic properties. It has also been reported that addition of cations such as Ca and Mg improved the FS of protein [10].

\section{CONCLUSION}

The results of this study demonstrated that addition of $\mathrm{NaCl}$ at a concentration of 0.4 to $0.6 \mathrm{M}$ significantly improved the protein solubility, foaming stability and emulsifying activity of pigeon pea, cowpea, white bean and hyacinth bean flours. Whereas, it significantly decreased the emulsion stability and foaming capacity of all the selected legume flours, the maximum improvement of both properties was observed at $0.2 \mathrm{M} \mathrm{NaCl}$, and it decreased gradually at higher salt concentrations. Based on these results, the selected legume flour demonstrated good functional properties following the addition of $\mathrm{NaCl}$ which makes these legume flours potential ingredients for application in salt containing foods. 


\section{REFERENCES}

1. Deshpande SS Food legumes in human nutrition: a personal perspective. Rev. Food Sci. Nutr. 1992; 32: 333-63.

2. Myers W In: Sustainable food security for all by 2020. Proceedings of an International Conference. Washington, D.C: IFPRI. 2002; p 100.

3. Bhat $\mathbf{R}$ and AA Karim Exploring the Nutritional Potential of Wild and Underutilized Legumes. Comp. Rev. Food Sci. Food Safety, 2009; 8: 305-331.

4. Vietmeyer ND Lesser-known plants of potential use in agriculture and forestry. Science, 1986; 232:1379-84.

5. Doyle JJ Phylogeny of the legume family: an approach to understanding the origins of nodulation. Ann. Rev. Ecol. Syst. 1994; 25: 325-49.

6. Ali $\mathbf{M}$ and S Kumar Problems and prospects of pulses research in India. Indian Farm, 2000; 50: 4-13.

7. Famurewa JAV and AO Raji Parameters affecting milling qualities of undefatted soybeans (Glycine max L. Merill) (1) selected thermal treatment. Int. J. Food Eng. 2005; 1:1-9.

8. Kinsella JE Functional properties of protein in foods: A survey. Crit. Rev. Food Sci. Nutr. 1976; 7: 219-280.

9. Johnson DW Oilseed proteins properties and application. Food Prod. Dev. 1970; 3: 70-78.

10. Fennema RO Food chemistry, ( $3^{\text {rd }}$ edition). Marcel Dekker, Inc. New York, Basel. Hong kong. pp. 1996; 365-39.

11. AOAC. Official methods of analysis. $14^{\text {th }}$ ed. Association of Official Agricultural Chemists, Washington, D.C. 1984.

12. Aoki H, Taneyama O, Orimo $\mathbf{N}$ and I Kitagawa Effect of lipophilization of soy protein on its emulsion stabilizing properties. J. Food Sci. 1981; 46: 11921195.

13. Pearce KN and JE Kinsella Emulsifying properties of proteins: Evaluation of a hurbidimetric technique. J. Agric. Food Chem. 1978; 26: 716-723.

14. Kato A, Shimokawa $\mathbf{K}$ and $\mathbf{K}$ Kobayasi Improvement of the functional properties of insoluble gluten by pronase digestion followed by dextran conjugation. J. Agric. Food Chem. 1991; 35: 200-205. 
15. Lawhon JT, Cater CM and KF Mattil A comparative study of the whipping potential of an extract from several oilseed flours. Cereal Sci. Today 1972; 17: 240-244.

16. Ahmed EA and RH Chmidt Functional properties of peanut and soybean proteins as influenced by processing method. Peanut Sci. 1979; 6: 1-8.

17. Snedecor GW and WG Cochran Statistical methods $\left(17^{\text {th }}\right.$ ed). Ames, IA: The Iowa State University Press, pp. 1987; 221-222.

18. Duncan DB Multiple range and F-test. Biometrics 1955; 11: 1-42.

19. Ali N A, Ahmed SH, Mohamed EA, Mohamed Ahmed IA and E E Babiker Effect of Transglutaminase Cross Linking on the Functional Properties as a Function of $\mathrm{NaCl}$ Concentration of Legumes Protein Isolate. Int. J. Biol. Life Sci. 2011; 7(1): 8-13.

20. Aluko RE and RY Yada Relationship of hydrophobicity and solubility with some functional properties of cowpea (Vigna unguiculuta) protein isolate. J. Sci. Food Agric. 1993; 62: 331-335.

21 McWatter $\mathbf{K H}$ and MR Holmes Influence of $\mathrm{pH}$ and salt concentration on nitrogen solubility and emulsification properties of soy and peanut flours. $J$. Food Sci. 1979; 44: 770-773.

22. Osman NM, Amro BH, Mohamed Ahmed IA and EE Babiker Effect of autoclaving on solubility and functional properties of chickpea (Cicer arietinum) flour as a function of salt concentration. J. Food Technol. 2005; 3: 336-341.

23. Kinsella JE Functional properties of soy proteins. J. Am. Oil Chem. Soc. 1979; 56: 242-257.

24. Monteiro PV and V Prakash Functional properties of homogenous protein fractions from peanut (Arachis hypogaea L.). J. Agric. Food Chem. 1994; 42: 274-278.

25. Aluko RE and RY Yada Structure-function relationships of cowpea (Vigna unguiculata) globulin isolate, influence of $\mathrm{pH}$ and $\mathrm{NaCl}$ on physicochemical and functional properties. Food Chemistry 1995; 53: 259-265.

26. McWatters KK and JP Cherry Emulsification, foaming and protein solubility properties of defatted soybean, peanut, field pea and pecan flours. $J$. Food Sci. 1977; 42: 444.

27. Odoemelam SA Functional properties of raw and heat processed jack fruit (Artocarpus heterophyllus) flour. Pak. J. Nutr. 2005; 4: 366-370.

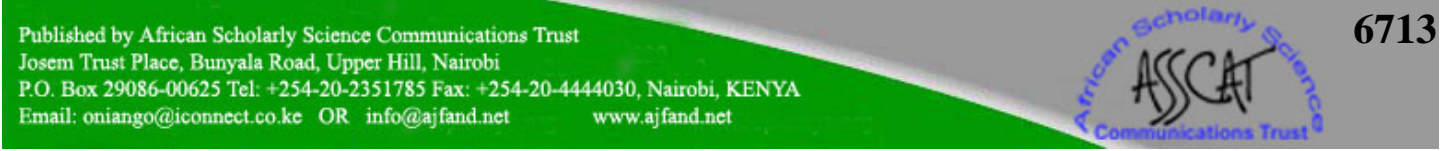


28. Wagner JR and J Guegeon Surface functional properties of native, acid treated and reduced soy glicilin II: Emulsifying properties. J. Agric. Food Chem. 1999; 47: 2181-2187.

29. Narayana K and MSN Rao Functional properties of raw and heat processed winged bean (Psophocarpus tetra-gonolobus) flours. J. Food Sci. 1982; 47: 1534.

30. Giami SY Effects of processing on the proximate composition and functional properties of cowpea (Vigna unguiculata) flour. Food Chem. 1993; 47: 153158. 